\title{
Growth Curve and Development of the Internal Calli Structure of Eucalyptus camaldulensis Dehn
}

\author{
Evânia Galvão Mendonça ${ }^{1 *}$, Luciano Vilela Paiva ${ }^{1}$, Vanessa Cristina Stein $^{2}$, Marinês \\ Ferreira Pires ${ }^{1}$, Breno Régis Santos ${ }^{3}$ and Fabricio José Pereira ${ }^{1}$ \\ ${ }^{1}$ Universidade Federal de Lavras; C. P.: 3637; 37200-000; Lavras - MG - Brasil. ${ }^{2}$ Universidade Federal de Goiás; \\ Rod. BR-364, Km 192; C. P.: 3; 75801-615; Jataí - GO - Brasil. ${ }^{3}$ Universidade Federal de Alfenas; Rua Gabriel \\ Monteiro da Silva, 700; 37130-000; Alfenas - MG - Brasil
}

\begin{abstract}
The objective of this work was to elucidate the growth curve of Eucalyptus camaldulensis Dehn. calli analyzing their anatomical modifications. A sigmoid aspect of the growth curve of the calli fresh matter was observed, with five different phases (lag, exponential, linear, deceleration and decline). In the lag phase, the highest growth percentage $87 \%$, was observed, which reduced during the evaluation period to $17 \%$ in the linear phase. As for the anatomical analyses, cellular multiplications was observed during the lag and exponential phases and increase in cell size during the linear phase, promoting the calli volume growth and the establishment of the globular conformation.
\end{abstract}

Key words: in vitro cultivation, organogenesis, anatomy, Astra blue, Safranin, forestry

\section{INTRODUCTION}

The genus Eucalyptus includes most of the forest species used in the establishment of plantations in the tropical and subtropical areas of the world. In function of its rusticity, the species Eucalyptus camaldulensis Dehn. is one of the most appropriate for reforestation in the critical areas, mainly those where hydric and edaphic deficiencies occur that limit the development of other species (Higa 2003).

To supply a constantly demanding market for the amount and quality of wood derived products and maintaining the consonance with the appeal for the preservation of the native forests throughout the world, the planted forests should produce increasing amounts of biomass in a shorter time and, if possible, in more restricted areas. With this purpose, the biotechnology has been presenting the opportunities for mass cloning and genetic transformation of superior genotypes (Xavier et al. 2001, García-Gonzáles et al. 2010). The application of plant tissue culture techniques, such as micropropagation, is a viable method for the large scale clonal propagation of various forest species, because as a main advantage it presents fast increase of the number of individuals and the possibility of germplasm conservation that can guarantee species biodiversity maintenance (Echeverrigaray et al. 2001).

Among the micropropagation techniques, the indirect organogenesis is one of the most used, for providing a high sprout regeneration rate starting from calli (Lainé and David 1994; Moralejo et al. 1998). But, especially for Eucalyptus, the micropropagation through shoot proliferation axillary has been the most used, being simpler than the mbryogenesis somatic or indirect organogenesis, because is based on the proliferation buds preformed (Gomes and Canhoto

*Author for correspondence: evaniafloresta@hotmail.com 
2003; Xavier et al. 2009). Watt et al. (2003), studied the direct organogenesis route via axillary bud proliferation largely studied in Eucalyptus, whereas only eight species were regenerated indirectly from the callus.

The formation of calli into an explant is a basic stage for the development of mass plants propagation systems by organogenesis or somatic embryogenesis and it is also useful when one wants to produce the cells for the genetic manipulations, such as somatic hybridizations, polyploidyzation and transformations (Venturieri and Venturieri 2004).

Somatic embryogenesis technology is expected to play a significant role in future forest tree improvement programs. Methods for the efficient SE propagation in softwood species based on the bioreactors are underway (Sun et al. 2010). Furthermore, genetic transformation through somatic embryogenesis is also the most promising approach to generate and propagate the elite recalcitrant genotypes of forest trees (Andrade et al. 2011), or clonal propagation of the selected endangered high-value forest trees (Merkle et al. 2007 and Pijut et al. 2011). The lack of an efficient protocol for the somatic organogenesis/embryogenesis is the bottle neck for the genetic manipulation of selected eucalyptus clones (Tournier et al. 2003; Aggarwal et al. 2010).

The organogenic events occur by dedifferentiation and cellular redifferentiation, depending on the resumption of the meristematic activity in the mature differentiated cells or in disorganized callus tissue. The in vitro organogenesis process is complex, with the involvement of multiple external and internal factors, being influenced by the genotype, the explant type, the makeup of the culture medium and by the cultivation environment (Joy IV and Thorpe 1999). Considering the influence of the explant, the use of those that contain a higher proportion of meristematic tissue is recommended, or those that present higher capacity to express totipotency (George 2008). The greatest advantage of using the indirect organogenesis as a tool for the clonal mass production and regeneration of plants is its potential of developing high multiplication rates, reproducing large amounts of uniform plants (Arenhart and Zaffari, 2008, Khan et al. 2011). The present study had as an objective to determine the growth curve of calli of E. camaldulensis Dehn. and describe the anatomical modifications occurring along its development.

\section{MATERIAL AND METHODS}

\section{Growth curves}

Foliar segments of Eucalyptus camaldulensis Dehn. plants cultivated in vitro and maintained in a growth room under the photoperiod of $16 \mathrm{~h}$, with irradiance of $40 \mu \mathrm{mol} \mathrm{m} \mathrm{m}^{-2} \mathrm{~s}^{-1}$ and temperature conditions of $27 \pm 2^{\circ} \mathrm{C}$, were used as explants. The foliar segments with approximately $1.0 \mathrm{~cm}^{2}$ were inoculated in the test tubes, containing $10 \mathrm{~mL}$ of LCBM - 4: MS culture medium (Murashige and Skoog 1962) with half concentration of nitrate and suplemented with $0.3 \%$ of sucrose, $0.45 \%$ of agar, $10 \%$ of commercial coconut water (Kero Coco ${ }^{\circledR}$ ), $4.5 \mu \mathrm{M}$ of BAP and $2.8 \mu \mathrm{M}$ of ANA. The $\mathrm{pH}$ was adjusted to 5.8 before sterilization by autoclaving at $121^{\circ} \mathrm{C}$ for 20 minutes, and after inoculation, the explants were maintained in a growth room at $27 \pm 2^{\circ} \mathrm{C}$ in the absence of light.

For the growth curve and anatomical analyses, the explants samples were analyzed at the first day (time 0); subsequently at intervals of 9 day, until the $99^{\text {th }}$ day, generating 12 analysis point. For this, 50 test tubes were inoculated and 10 tubes were randomly selected to accompany the fresh weight. To obtain the fresh weight, the explnats were carefully placed in sterile petri dish, sealed with plastic wrap, keeping thus the aseptic conditions so they could return to the culture medium. The calluses were weighed with the aid of a precision scale and the analysis was performed from the same fresh weight of 10 corns. The growth percentage of the calli was determined according to the equation determined by Lameira et al. (1996):

$$
\% \text { growth } \frac{W_{f}-W_{i}}{W_{f}} \times 100
$$

$\mathrm{W}_{\mathrm{i}}$ being = initial weight and $\mathrm{W}_{\mathrm{f}}=$ final weight of calli

The growth rate was calculated according to Teixeira et al. (2004) by the following formula:

$$
\mathrm{AGR}=\frac{\ln \mathrm{W}_{f}-\ln \mathrm{W}_{i}}{t}
$$

AGR being $=$ average growth rate; $\ln =$ neperian logarithm; $\mathrm{W}_{\mathrm{f}}=$ final weight of the fresh matter; 
$\mathrm{W}_{\mathrm{i}}=$ initial weight of the fresh matter and $\mathrm{t}=$ the cultivation period, in days.

\section{Anatomical analysis}

For the anatomical analysis, the calli collected at 9 day intervals were fixed in FAA $70 \%$ (formaldehyde, acetic acid and ethanol 70\%) for $48 \mathrm{~h}$ and, later, preserved in $70 \%$ ethanol (Johansen 1940). After the fixation, the material was cut in transverse sections, using a table microtome. The cuts were clarified with sodium hypochlorite at $1 \%$ and stained with a $0.1 \%$ Astra Blue solution and $1 \%$ Safranin at a proportion of $7: 3$, in the case of the points 1 and 2 and with Astra Blue $0.1 \%$ in the case of the other points. Glycerin (50\%) was used for the assembly of the semipermanent slides and nitrocellulose resin for sealing of the coverslips. The slides were observed under an optical microscope and the best fields were photographed and used for the anatomical parameter measurements using the software
UTHSCSA-Imagetool calibrated with a photographed microscopic ruler.

The appraised anatomical parameters were cell density, cell wall thickness, DC $=$ diameter of the cells of the basic parenchyma, DEC $=$ density of cells of the basic parenchyma (number of cells per $\left.\mathrm{mm}^{2}\right), \mathrm{EP}=$ epidermis thickness, $\mathrm{CAL}=$ callus diameter. The statistical analysis was conducted with the Sisvar software (Ferreira, 1999), carrying out the regression analysis.

\section{RESULTS}

The general aspect of the formation of the calli induced in vitro, based on foliar segments of $E$. camaldulensis Dehn. inoculated in LCBM-4 culture medium supplemented with cytokinin, auxin and coconut water is shown in Figure 1 from the inoculation up to 99 days of cultivation.

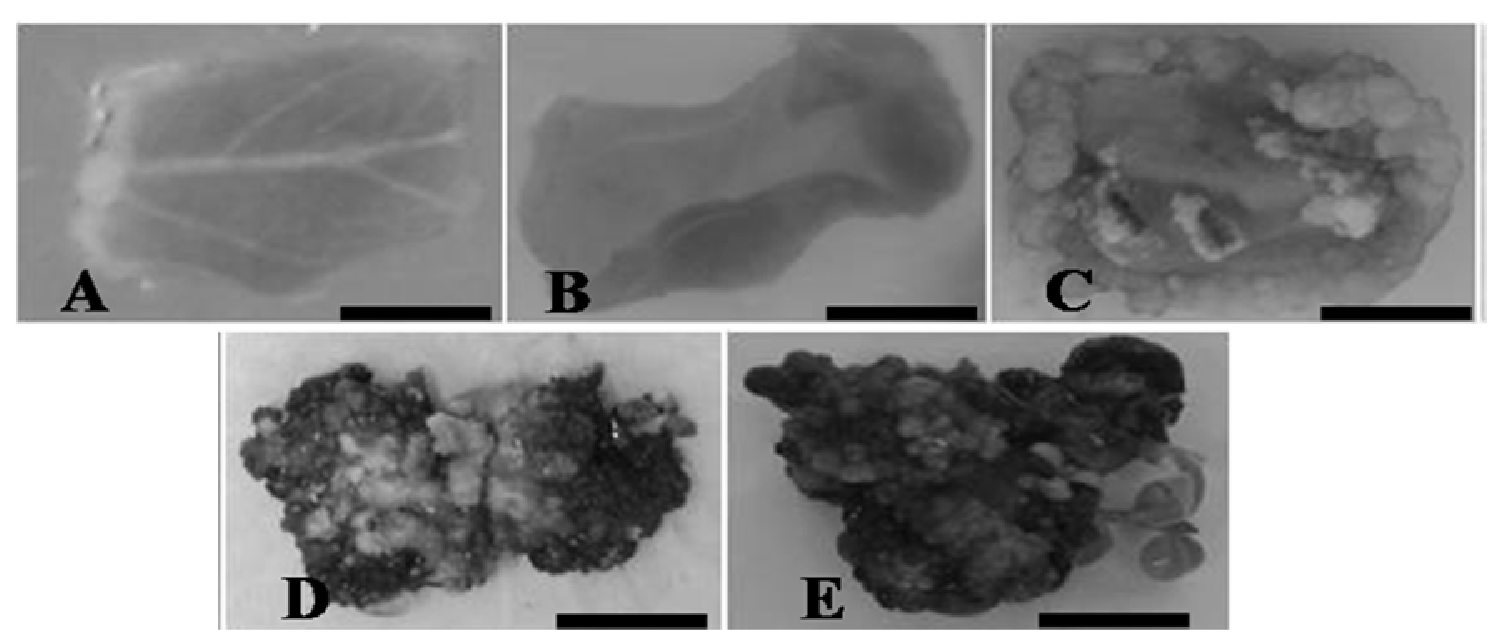

Figure 1- General appearance of calli of E.camaldulensis Dehn. formed from leaf segments inoculated in vitro in 4-LCBM culture medium supplemented with cytokinin, auxin and coconut water. A- after inoculation, B-9 days, C-36 days, D-72 days, E-99 days (Bar $5 \mathrm{~mm})$.

The development of the calli in the foliar explant of Eucalyptus camaldulensis Dehn. occurred approximately on the 20th day, beginning in the areas close to the central rib of the leaves, with the growth and division of the basic parenchyma cell, towards the abaxial face (Fig. $2 \mathrm{~A}$ and $\mathrm{B}$ ). The results regarding the evaluations of the calli growth can be observed in Figure 3. The graphs regarding the average calli weight (Fig. 3A), growth percentage (Fig. 3B) and average growth rate (Fig. 3C) referred to the data of real growth, since the same calli were weighed at all the 12 points of the curve. 


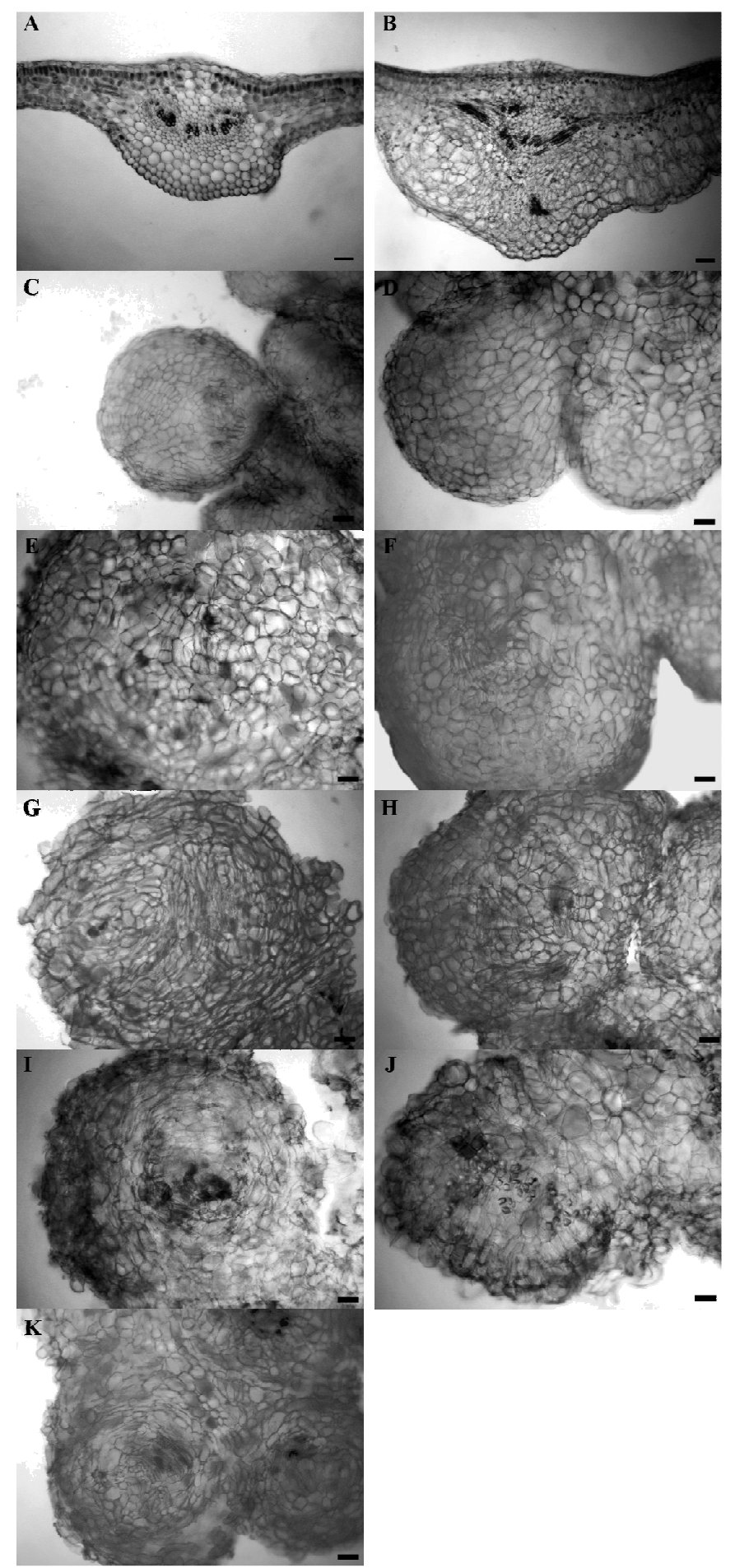

Figure 2 - Development of organogenic calli of $E$. camaldulensis Dehn. over time. $\mathrm{A}=0$ days, $\mathrm{B}=$ 9 days, $\mathrm{C}=18$ days, $\mathrm{D}=27$ days, $\mathrm{E}=36$ days, $\mathrm{F}=45$ days, $\mathrm{G}=54$ days, $\mathrm{H}=63$ days, $\mathrm{I}=$ 72 days, $\mathrm{J}=81$ days, $\mathrm{K}=90$ days. $\mathrm{Bar}=50 \mu \mathrm{m}$.

The growth curve of the calli was linear, with a tendency towards the fresh matter gains in the function of the cultivation time increase. In the analysisd period (99 days of cultivation), four different growth phases were observed (lag, exponential, linear and deceleration), not detecting the decreasing and the stationary phase (Fig. 3A). 

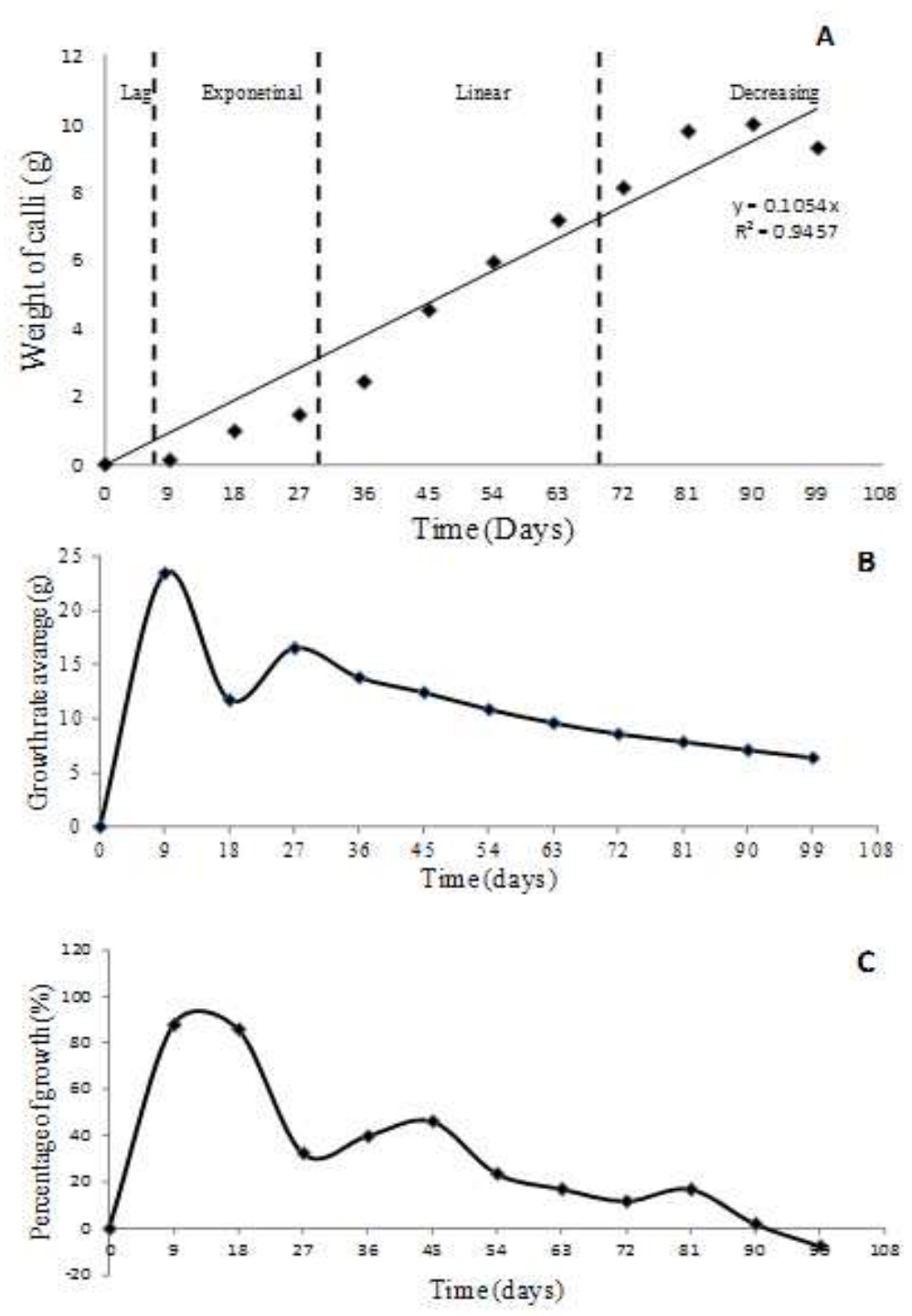

Figure 3 - Growth curve indicating the growth and development of calli of Eucalyptus camaldulensis Dehn. A - Average weight (grams/day); B - Growth percentage; C Average growth rate (grams/day).

The lag phase, in which the cells of the explant became ready for the cell division, accumulating the biomass, occurred until the 9th day of inoculation, the period in which the highest growth rate was observed ( 0.23 grams/day) and the highest growth percentage, (87\%). As for the internal analysis of the calli, a reduction of $57.94 \%$ in the cell diameter was also observed, which changed from $36.38 \mu m$ to $15.30 \mu m$ (Fig. 4A) and the cell density changed from 1600.00 at time 0 , to 2410.67 after 9 days, indicating intense cell division (Fig. 4 B).

The exponential growth phase, a period in which the maximum cellular division occurred took place between the $9^{\text {th }}$ and the $36^{\text {th }}$ day after inoculation, with an average growth rate $0.14 \mathrm{~g} /$ day and $40 \%$ calli growth. The intense cell division, until the $36^{\text {th }}$ day, provided the cell diameter increase (Fig. $4 \mathrm{~A}$ ), and consequently the diameter of the calli, that went from $0.00 \mu \mathrm{m} \mathrm{m}$ at 9 days to $951.14 \mu \mathrm{m}$ at 36 days (Fig. 5 B). The reduction in cell density observed between the $9^{\text {th }}$ and $36^{\text {th }}$ days ( 2410.67 to 1377.78 , respectively) was due to the volume increase of the callus and not to the apparent reduction of the cell division activity. During the period between the $18^{\text {th }}$ and $27^{\text {th }}$ day, the typical globular morphology for those calli was established (Fig. 2C and 2D). 

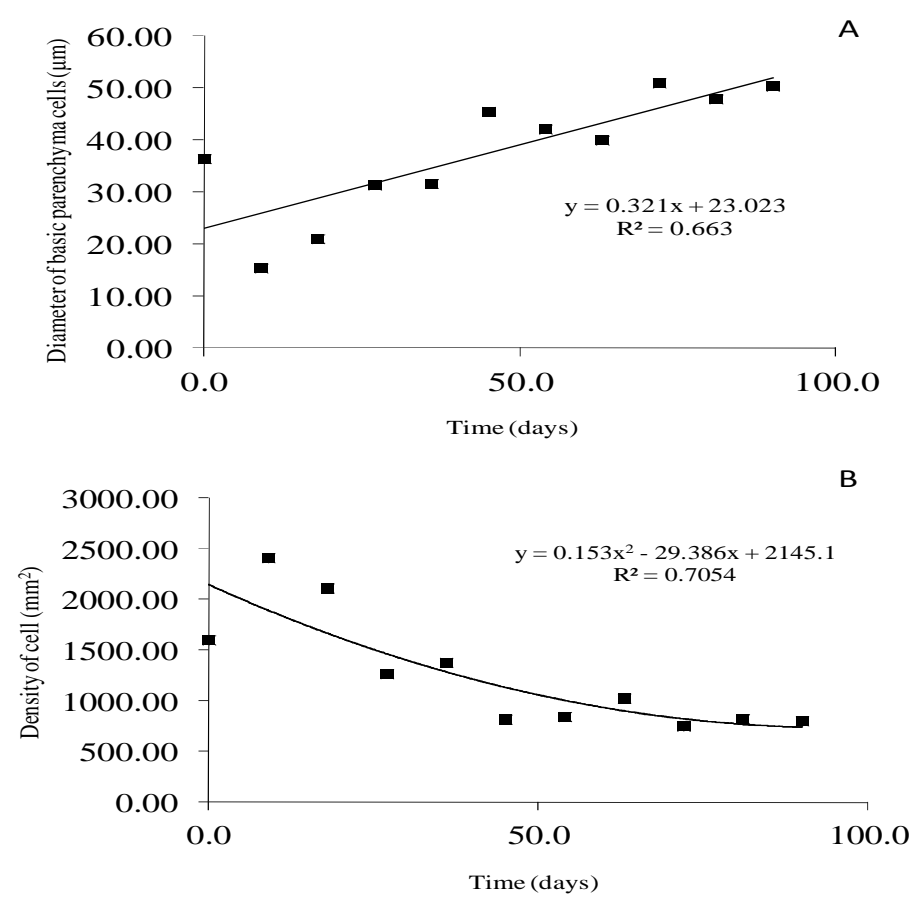

Figure 4 - Changes in anatomical characteristics of the calli formed from leaf explants of $E$. camaldulensis over several days (points) during their development. A) Diameter of the basic parenchyma cells, B) density of basic parenchyma cells (no. per $\mathrm{mm}^{2}$ ).
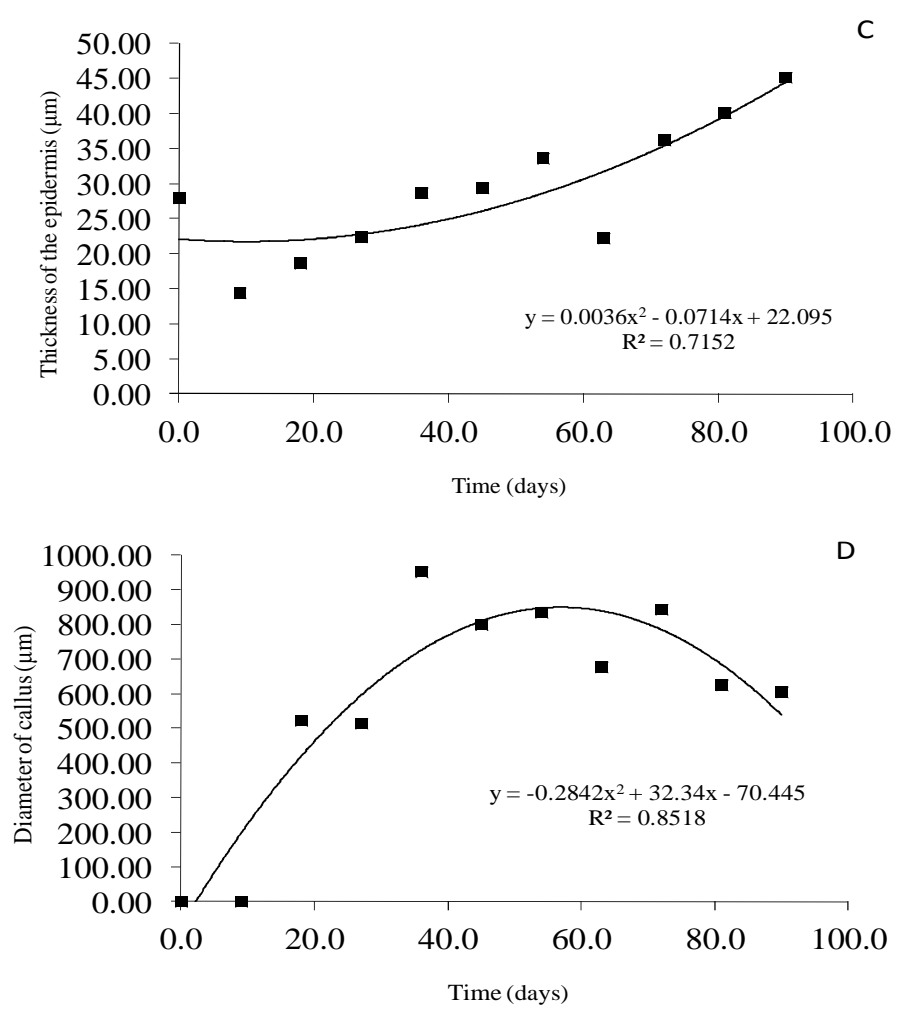

Figure 5 - Changes in anatomical characteristics of the calli formed from leaf explants of $E$. camaldulensis over several days (points) during their development. A) epidermal thickness and B) callus diameter. 
The linear growth was observed between the 36th and the 81st day of cultivation, presenting a growth rate of only $0.08 \mathrm{~g} /$ day that corresponded to $17 \%$ of the growth (Fig. 3A). In this period, there was decrease in the cell division rate internally and consequent stabilization of the cell density and callus volume. There was an increase in the cell diameter that changed from 31.59 to $47.87 \mu m$ (Fig. 4A).

As a response to the metabolic changes, after the cellular multiplication occurred during the exponential phase in the linear phase an increase was observed in cell volume and of the calli establishing the typical globular formation (Fig. $2 \mathrm{G}$ to $2 \mathrm{~J}$ ). This morphology was maintained from the 45th day (Fig. 2), giving rise to the sprouting completely developed into the plants (Fig. $1 \mathrm{E}$ ).

The deceleration interval of the growth was observed between the 81th and the 90th day of inoculation, with a growth rate of only $0.07 \mathrm{~g} / \mathrm{day}$, representing $2 \%$ of the growth. Corroborating that data, the anatomical analysis revealed the stabilization of the diameter and the density of the cells and the lessening of the callus diameter. At this time, the proliferation of adventitious buds was also observed (Fig. $1 \mathrm{E}$ ).

\section{DISCUSSION}

The morphogenic responses observed during the growth curve of Eucalyptus camaldulensis Dehn.calli are of great interest, considering the potential of the biotechnology and the tissue cultures to accelerate the improvement programs. The biotechnological processes that can be applied to the micropropagation of selected clones could reduce the time involved in the improvement of woody plants. Thus, the production of eucalyptus trees, starting from the clonal material is considered a more attractive perspective than the production of the trees from the germination of seeds that possess unknown agronomical characteristics.

The growth curve of the calli presented four different growth phases (lag, exponential, linear, deceleration); the decline and stationary phases were not detected. The lag phase occurred until the $9^{\text {th }}$ day. However, several studies have demostrated that the period of the lag phase varies according to the species studied. In the studies on the growth curve of calli obtained through the foliar segments of the pequi tree (Caryocar brasiliense Camb), Landa et al. (2000) observed the occurrence of the lag phase till the $7^{\text {th }}$ day of cultivation. Dibax et al. (2010) observed that the initial morfogenetic response in the calli of Eucalyptus camaldulensis Dehn was the turgidity of the explant after 7 days of in vitro culture.

The importance of anatomical studies was reported by Hervé et al. (2001) and Carvalho et al. (2004). For these authors, the histological analysis in studies organogenesis in vitro is fundamental to confirming the source of buds formed in culture, excluding the possibility of misinterpretation the results arising from the presence of gems preformed in the original explant and Hervé et al. (2001) the knowledge of the exact site where the cell divisions begin before calli formation is important for studies of genetic transformation, because they indicate the surface of origin of the adventitious shoots.

The anatomical observations conducted in the foliar explants cultivated for 9 days revealed that the highest development of the calli occurred in the area of the central rib. Histological study have indicated that the cell proliferation began at the cut surface of the explants from the parenchymatic and vascular cylinder cells (San-Jose et al. 2010; Gueye et al. (2009). The nodular or friable calluses can be formed from the activity of cells perivascular sheath. Marín-Méndez et al. (2009) observed the differentiation of the procambium bands into the ascular tissues, xylem and phloem. Hervé et al. (2001) observed that in Eucalyptus gunnii, the formation of calli in the leaf was connected to the foliar vessels, since numerous cell divisions took place in the cells close to the tracheal elements. This strongly suggested that the protuberances observed on the surface of the explant originated from the leaf vascular exchange system cells, although the hypothesis could not be excluded that some cells also originated from the fascicular parenchyma as was observed by. Dibax et al. (2010) for Eucalyptus camaldulensis Dehn, where the buds were formed on the calli developed from the mesophyll of the abaxial face of the leaf. Most of the works with the callus have observed that the best shoot regeneration capacity, starting from the calli, could be associated with the meristematic origin of the calogenic protuberance as reported by Barueto-Cid et al. (1999). This could be related to the presence of nutrients and photoassimilates in the xylem and phloem that were the main nutrient translocation points in the leaves (Castro et al. 2009). 
The exponential growth phase occurred between the $9^{\text {th }}$ and $36^{\text {th }}$ day after the inoculation where the calus formation, intense cell division and cell diameter increase was observed. According to Taiz and Zeiger (2004), the plant growth occurs in two stages: the increase of the number of cells and the increase of the cell size. Therefore, the small sized cells and the high density at nine days allowed to infer that this was the beginning of the exponential phase, when the most intense cell division occurred. The increase in the cell diameter during the interval between the $9^{\text {th }}$ and the $36^{\text {th }}$ day indicated the establishment of this phase. For Quercus robur trees, the callus proliferation was observed within two weeks following the culture initiation, first developing at the proximal cut surface and then progressing towards the distal end (San-Jose, et al. 2010). Dibax et al. (2010) observed the formation of shoots on Eucalyptus camaldulensis Dehn after 45 days, either in the midrib region or basal petiole region or apical region of the leaf.

The lag phase can be considered as the energy producing phase and the exponential phase as the biosynthetic phase. The histological information will contribute to a more accurate determination of the optimal anatomical stages for a stable integration of foreign genes and the suitable conditions for in vitro culture for the regeneration of transgenic plants (Marín-Méndez et al. 2009).

The linear growth period was observed between the 36th and the 81th day of the cultivation, where the decrease in the division and consequent stabilization of the cells density and volume occurred, with the maintenance of the globular form and proliferation of the buds. Dibax et al. (2010) observed that the callis of E. camaldulensis Denh., after 45 days were highly developed and showed concentric groups of vascular cells and adventitious buds with visible shoot meristems. Alcantara et al. (2010) observed the formation of buds 20 to $30 \mathrm{~d}$ after the transfer of explants of Eucalyptus grandis $\times$ Eucalyptus urophylla for a bud induction medium. In Cedrela odorataca L. almost all the explants, after 36th in induction medium, had responded by forming the calli and some masses of calli classified as friable and continued to grow, produced organogenic structures, but most became necrotic and died (Pena-Ramirez et al. 2011).
The growth deceleration interval was observed between the 81st and 90th day of inoculation, with the stabilization of the cell diameter and density, diminuation of the diameter of the callus probably due to the cell death caused by a scarcity of nutrients. According to Smith (1992), it is in that phase that the calli should be collected for multiplication, in reason, mainly, of the nutrient reduction, the drying of the agar, or even the accumulation of toxic substances in the culture medium, that arise as a consequence of the oxygen reduction inside the cells. In that context, the results indicated that the transfer of calli from the leaves of E. camaldulensis Denht should be done before the beginning of the deceleration phase; in other words, on the 72nd day of cultivation so that there was no compromise of the multiplication and the cell division. Similar results were found by Lima et al. (2007) who studied the growth curve of calli of sangra-d água (Croton urucurana). They also recommended that the transfer was made close to 70 days after inoculation.

After 45 and $60 \mathrm{~d}$ in the presence of NAA and BAP, the calli were highly developed and showed concentric groups of vascular cells and adventitious buds with visible caulinar meristems. The results presented by the calli growth curve of E. camaldulensis Denh. formed based on foliar segments indicated that the high percentage of growth reached in the lag phase at the 9th day of cultivation was associated to the fast growth of the species, which, possibly was due to the occurrence of fast cellular cycle. The observation of the growth curve of the calli also aided in the understanding of the in vitro cellular behavior and provided the optimization of the culture manipulation in order to assist the species improvement objectives.

\section{CONCLUSION}

The growth curve of calli fresh matter formed from the foliar explants of E. camaldulensis presented a curve growth, with four different phases for the morphological and anatomical characteristics. The anatomical characteristics could aid in the analysis and understanding of the growth curve of the calli. 


\section{REFERENCES}

Alcantara GB, Bespalhok Filho JC, Quoirin M. Organogenesis and transient genetic transformation of the hybrid Eucalyptus grandis $\times$ Eucalyptus urophylla. Sci. Agric. 2011; 68(2): 246-251.

Alves ECSC, Xavier A, Otoni WC. Organogênese in vitro a partir de explante caulinar na regeneração de clones de Eucalyptus grandis W. Hill ex Maiden x $E$. urophylla S. T. Blake 1. Rev. Árvore. 2004; 28(5): 643-653.

Andrade G, Shah R, Johansson J, Pinto G, Egertsdotter, U. Somatic Embryogenesis as a tool for forest tree improvement: a case- study in Eucalyptus globulus. BMC Proceedings 5 (Suppl 7). 2011; 128.

Andrade GM, Nairn CJ, Le HT, Merkle AS. Sexually mature transgenic American chestnut trees via embryogenic suspension-based transformation. Plant Cell Rep. 2010; 28: 1385-1397.

Aggarwal D, Kumar A, Reddy M.S. Shoot organogenesis in elite clones of Eucalyptus tereticornis. Plant Cell Tiss Organ Cult., on line. 2010.

Arenhart R.A, Zaffari GR. Otimização do protocolo de icropropagação por organogênese indireta de Eucalyptus grandis. Rev de Ciências Agroveterinárias. 2008; 7: 16-22.

Barrueto-Cid LP, Machado ACM, Carvalheira SRC, Brasileiro ACM. Plant regeneration from seedling explants of Eucalyptus grandis $x$ E. urophylla. Plant Cell Tiss Organ Cult. 1999; 56: 17-23.

Castro EM, Pereira FJ, Paiva R. Histologia Vegetal: Estrutura e Função de Órgãos Vegetativos, ed. UFLA, Lavras; 2009; 234.

Dibax R, Quisen RC, Bona C, Quoirin M. Plant Regeneration from Cotyledonary Explants of Eucalyptus camaldulensis Dehn and Histological Study of Organogenesis in Vitro. Braz. Arch. Biol. Technol. 2010; 53: 311-318.

Echeverrigaray S, Andrade LB, Delamare APL, Zeni ALB, Carrer R. Cultura de tecidos e micropropagação de plantas aromáticas e medicinais. In: Torres AC, Caldas LS, Buso JA. Biotecnologia na agricultura $e$ na agroindústria. 2001; 257-276.

Ferreira DF. SISVAR 4.3: Sistema de analises estatísticas, Lavras; 1999.

García-Gonzáles R, Quiroz K, Carrasco B, Caligari P. Plant tissue culture: Current status, opportunities and challenges. Cien. Inv. Agr. 2010; 37(3): 5-30.

George, E.F. Plant Tissue Culture Procedure Background. George E.F; Hall M.A.; Klerk G.J. In: Plant propagation by tissue culture. vol.1 The Background, 3rd edition. Springer, Dordrecht; 2008: 501.
Grattapaglia D, Machado MA. Micropropagação. In: Torre AC, Caldas LS. Técnicas e aplicações da cultura de tecidos de planta. 1990: 99-169.

Gomes F, Canhoto JM. Micropropagationm of Eucalyptus nitens Maiden (Shining gum). In Vitro Cell \& Develop Biol - Plant. 2003; 39(3): 316-321.

Gueye B, Saïd-Ahmed H, Morcillo F, Borgel A, Sane D, Hil Bert JL, et al. Callogenesis and rhizogenesis in date palm leaf segments: are there similarities between the two auxininduced pathways. Plant Cell, Tissue and Organ Culture. 2009; 98: 47-58.

Hervé P, Jauneau A, Pâques M, Marien JN, Boudet AM, Teulières C. A procedure for shoot organogenesis in vitro from leaves and nodes of an elite Eucalyptus gunnii clone: comparative Phistology. Plant Sci. 2001; 161: 645-653.

Higa, R.C.V. Descrição de algumas espécies de eucalipto. Rev da Madeira. 2003; 13: 8-17.

Joy IV RW, Thorpe TA. Shoot morphogenesis: structure, phusiology, biotecmistry and biology. In: Soh WY, Bhojwani SS. (Ed.). Morphogenesis in plant tissue cultures; 1999. p. 171-214.

Johansen, D. A. Plant microtechnique, 2. ed. New York: Mc-Graw-Hill; 1940. 523 p.

Khan H, Siddique I, Anis M, Khan PR. In vitro organogenesis from internode derived callus cultures of Capsicum annuum L. J. Plant Biochem. Biotechnol. 2011; 20(1) 84-89.

Lameira AO, Pinto JEBP, Arrigonii-Blank MF, Pereira FD. Estabelecimento da curva de crescimento em calos de Erva-baleeira (Cordia Verbenacea L.). Hortic. Brasileira 1996; 4: 92-93.

Lainé, E.; David, A. Regeneration of plants from leaf explants of micropropagated clonal Eucalyptus grandis. Plant Cell Reports . 1994; 13: 473-476.

Landa FSL, Paiva R, Paiva PDO, Bueno Filho JSS. Indução in vitro de calos em explantes foliares de pequizeiro (Caryocar brasiliense Camb.). Ciênc. Agrotec. 2000; 24: 56-63.

Lima EC, Paiva R, Soares FP, Nogueira RC, Emirch EB, Nicioli PM. Avaliação bioquímica do desenvolvimento de calos in vitro a partir de segmentos foliares de Sangra d’água (Croton urucurana Baill.). Magistra. 2007; 19: 1055-1065.

Marín-Méndez W, Sanchéz-Chacón E, Gatica-Arias AM, Ramírez-Fonseca Pilar, Freer-Bustamante E, Valdez-Melara M. Ultrastructure and histology of organogenesis induced from shoot tips of maize (Zea mays, Poaceae). Rev. Biol. Trop. 2009; 57: 129-139.

Méndez WM, Sanchéz-Chacón E, Gatica-Arias AM, Ramírez-Fonseca P, Freer-Bustamante E, ValdezMelara M. Ultrastructure and histology of organogenesis induced from shoot tips of maize (Zea mays, Poaceae). Rev. Biol. Trop. 2009; 57: 129-139. 
Merkle SA, Andrade GM, Nairn CJ, Powell WA, Maynard CA. Restoration of threatened species: a noble cause for transgenic trees. Tree Genetics \& Genomes. 2007; 3: 11-118.

Moralejo M, Rochange F, Boudet AM, Teulieres C. Generation of transgenic Eucalyptus globulus plantlets through Agrobacterium tumefaciens mediated transformation. Australian Journal of Plant Physiology. 1998; 25: 207-212.

Peña-Ramírez YJ, García-Sheseña I, HernándezEspinoza A, Domínguez-Hernández A, Barredo-Pool FA, González-Rodríguez JA,et al. Induction of somatic embryogenesis and plant regeneration in the tropical timber tree Spanish red cedar Cedrela odorata L. (Meliaceae). Plant Cell Tiss Organ Cult. 2011; 105: 203-209.

Pijut PM, Lawson SS, Michler C.H. Biotechnology efforts for preserving and enhancing temperature hardwood tree biodiversity, health and productivity. In vitro Cell. Dev. Biol-Plant. 2011; 47: 123-147.

San-José MC, Corredoira E, Martínez MT, Vidal N, Valladares S, Mallón RAM. Shoot apex explants for induction of somatic embryogenesis in mature Quercus robur L. trees. Plant Cell Reports . 2010; 29(6): 661-671.

Serra AGP, Paiva R, Paiva PDO. Análises bioquímicas de calos formados de explantes foliares de castanhado-Brasil (Bertholletia excelsa H.B.K.). Ciênc $e$ Agrotec. 2000; 24: 833-840.

Shimizu T, Clitto A, Komamine A, Fowler MW. Changes in metabolite levels during growth of Acer pseudoplatanus (sycamore) cells in batch suspension culture. Physiol Plantarum. 1977; 40: 125-129.

Smith, R.M. Plant tissue culture: techniques and experiments; 1992: 171.

Sun H, Aidun CKA, Egertsdotter U. Possible effect from shear stress on maturation of somatic embryos of Norway spruce (Picea abies). Biotec and Bioengineering. 2010; 108: 1089-1099.
Taiz, L.; Zeiger, E. Plant Physiology, Sinauer Associates, Inc., Publishers. Sunderland, Massachusetts, (4 ed.); 2004.

Teixeira JB, Junqueira CS, Pereira AJ da C, Mello RIS, Silva APD, Mundim DA. Multiplicação clonal de café (Coffea arabica L.) via embriogênese somática. In- EMBRAPA. Documentos, 121, ed EMBRAPA, Brasília; 2004: 39.

Tournier V, Grat S, Marque C, El kayal W, Penchel R, Andrade G De, Boudet A, Teulières C. An efficient procedure to stably introduce genes into an economically important pulp tree (Eucalyptus grandis x Eucalyptus urophylla). Transg.Res. 2003; 12: 403411.

Venturieri GA, Venturieri GC. Calogênese do híbrido Theobroma grandiflorum X T. obovatum (Sterculiaceae). Acta Amazônica. 2004; 34: 507-511.

Xavier A, Andrade HB, Oliveira ML, Wendling I. Desempenho do enraizamento de microestacas e miniestacas de clones de híbrido de Eucalyptus grandis. Rev. Árvore. 2001; 25(4): 403-411.

Xavier A, Otoni WC, Penchel RM. Micropropagação e enxertia in vitro de espécies florestais. In: Borém, A. Biotecnologia florestal; 2007: 55-74.

Xavier A, Wendling I, Silva R L.(2009)

Silvicultura clonal: princípios e técnicas.

Viçosa, MG: Universidade Fedral de Viçosa, 272p.

Watt MP, Blakeway FC, Mokotedi MEO, Jain SM. Micropropagation of Eucalyptus. In: Micropropagation of woody trees and fruits Jain, S.M.; Ishii, K. (Eds.) Series: Forestry Sciences. 2003; 75: $852 \mathrm{p}$.
Received: April 25, 2011; Revised: August 16, 2011; Accepted: July 08, 2012. 